\title{
EFEK SAMPING KB SUNTIK KOMBINASI (SPOTTING) DENGAN KELANGSUNGAN AKSEPTOR KB SUNTIK KOMBINASI
}

\author{
Paramitha Amelia Kusumawardani ${ }^{1)}$, Hanik Machfudloh ${ }^{2)}$ \\ ${ }_{1,2}$ Pendidikan Profesi Bidan, Fakultas Ilmu Kesehatan, Universitas Muhammadiyah Sidoarjo, Sidoarjo, Indonesia \\ email: paramitha_amelia@umsida.ac.id
}

\begin{abstract}
Abstrak
Berbagai macam metode kontrasepsi tersedia baik berupa metode hormonal maupun metode non hormonal. Data Riskesdas 2018 menunjukkan KB suntik 3 bulan merupakan kontrasepsi hormonal yang paling banyak digunakan. Setiap kontrasepsi hormonal yang ada mempunyai efek samping termasuk KB suntik 3 bulan yang mengandung progestin. Dari data register yang diambil di PBM Desa Suko Kabupaten Sidoarjo, akseptor KB suntik 3 bulan hampir seluruh akseptor mengalami efek samping, Tujuan penelitian mengkaji efek samping KB suntik 3 bulan terhadap kelangsungan penggunaan KB suntik 3 bulan. Desain penelitian yang digunakan desain penelitian korelasi dengan menggunakan pendekatan cross sectional dengan studi retrospektif. Populasi pada penelitian seluruh akseptor KB suntik 3 bulan yang mengalami efek samping (spotting) di PBM Desa Suko Kabupaten Sidoarjo berjumlah 34 akseptor dan sampel yang diambil 31 akseptor.Teknik sampling menggunakan random sampling. Uji statistik Chi-Kuadrat dengan taraf signifikan 0,05 didapatkan ${ }_{2} \mathrm{X}$ sebesar 2,981823 sedangkan ${ }_{2} \mathrm{X}$ tabel Chi-Kuadrat dengan d.b=1 sebesar 3,481. Jadi didapatkan hasil ${ }_{2} \mathrm{X}$ hitung lebih kecil dari ${ }_{2} \mathrm{X}$ tabel Chi-Kuadrat maka hipotesa Ho diterima. Kesimpulan efek samping (spotting) tidak ada hubungan dengan kelangsungan penggunaan KB suntik 3 bulan.
\end{abstract}

Kata kunci: efek samping, spotting, kontrasepsi, KB suntik

\begin{abstract}
There are various contraceptive methods available, both hormonal and non-hormonal methods. The 2018 Riskesdas data shows that 3 months injection contraceptive is hormonal contraceptive most used. Every hormonal contraceptive has side effects including 3 months injection contraceptive that contains progestin. Based on registered data taken at PBM (Independence Midwife Practice) Suko village, Sidoarjo, almost all acceptors of 3-month injection contraceptive experience side effects, therefore researchers want to study side effects of 3-month injection contraceptive toward the continuity of using 3-month injection contraceptive. The research design used correlation research design using a cross sectional approach with a retrospective study. Population in study was 34 acceptor of 3 month injection contraceptive who experienced side effects (spotting) in PBM Suko village, Sidoarjo and the sample was 31 acceptors. Sampling technique uses random sampling. Chi-Square statistical test with a significant level of 0.05 was obtained ${ }_{2} X$ of 2.981823 while the ${ }_{2} X$ Chi-Square table with d.b $=1$ was 3.481. So the result is ${ }_{2} X$ count smaller than ${ }_{2} X$ Chi-Square table, so the Ho hypothesis is accepted. Conclusion of this study is that side effects (spotting) have no relationship with continuity of using injection contraceptives for 3 months.
\end{abstract}

Keywords: side effect, spotting, contraception, injection contraceptive

\section{PENDAHULUAN}

Penduduk Indonesia mengalami laju pertumbuhan dengan jumlah rata-rata sebesar $1,6 \%$ setiap tahun, hal ini merupakan jumlah yang terlalu tinggi dan dapat menimbulkan berbagai macam masalah. Masalah tersebut antara lain semakin berkurangnya lahan untuk pertanian, kemampuan untuk produksi lahan menurun, kebutuhan pokok yang sudah tidak mampu lagi diimbangi fasilitas sosial, semakin sedikitnya lowongan pekerjaan, rendahnya pendapatan penduduk dan persaingan yang ketat sehingga terjadi peningkatan urbanisasi (JNPKKR/POGI, BKKBN, 2014). Namun secara garis besar, Indonesia pada bidang kependudukan menghadapi masalah utama antara lain besaran penduduk yang besar dengan laju besaran pertumbuhan penduduknya yang relatif sangat banyak, struktur penduduk muda, penyebaran dari 
populasi yang tidak merata, dan kualitas dari penduduk yang harus ditingkatkan (Prasetyo, 2013).

Tiga aspek utama mempengaruhi tingkatan pada pertumbuhan populasi, antara lain fertilitas, mortalitas dan migrasi sehingga untuk menekan laju pertumbuhan penduduk dapat dilakukan dengan cara menekan angka dari kelahiran (fertilitas) (Kolifah et al., 2013). Hal ini dilakukan dengan suatu program pemerintah yang dinamakan program keluarga berencana (KB). Keluarga Berencana (KB) merupakan suatu program berskala nasional yang mempunyai tujuan untuk menekan dari angka kelahiran dan mengendalikan laju pertumbuhan populasi dalam suatu negara. Sasaran dari program KB yaitu menjadi terkendalinya laju pertumbuhan populasi dan semakin menumbuhkan keluarga yang mempunyai kualitas yang dilihat dengan pemakaian semakin tingginya penggunaan cara alat kontrasepsi yang logis, berhasil dan berdaya guna (Harini, 2010).

Berbagai macam metode kontrasepsi yang ada saat ini disediakan oleh pemerintah, baik berupa metode kontrasepsi hormonal maupun metode kontrasepsi non hormonal. Hal ini merupakan upaya pemerintah untuk meningkatkan kesejahteraan masyarakat khususnya dalam pengendalian laju pertumbuhan penduduk (Septianingrum et al., 2018). Data dari Riskesdas 2018 memperlihatkan kontrasepsi suntik 3 bulan adalah alat kontrasepsi hormonal yang paling tinggi dipakai masyarakat $(42,4 \%)$. Dari data pendahuluan yang dilaksanakan oleh peneliti di PBM Desa Suko Kabupaten Sidoarjo pada bulan Agustus-September 2020 menunjukkan bahwa dari 30 WUS yang menggunakan KB, 15 WUS merupakan akseptor KB suntik kombinasi, 8 akseptor KB suntik progestin, 2 akseptor KB IUD, 4 akseptor KB pil dan 1 akseptor $\mathrm{KB}$ implant sehingga dari data tersebut menunjukkan bahwa 50\% WUS menggunakan KB suntik kombinasi (3 bulan).

Setiap metode kontrasepsi yang ada mempunyai efek samping khususnya metode kontrasepsi hormonal termasuk kontrasepsi suntik 3 bulan adalah salah satu metode kontrasepsi hormonal yang mengandung progestin. Setelah akseptor menerima suntikan makan hormon progestin yang dikandung alat kontrasepsi mempunyai efek samping mengentalkan serviks sehingga sel sperma menjadi susah aktif kearah rahim. Selain itu, progestin ini juga menghalangi ovulasi dan dinding rahim menjadi tidak kondusif lagi bagi sel telur yang telah dibuahi. Kinerja pada hormon dapat memberikan efek samping pada tubuh akseptor KB. Efek samping yang mungkin timbul pada akseptor KB suntik 3 bulan yaitu adanya perubahan siklus menstruasi (menstruasi dapat menjadi lebih pendek, lebih panjang, flek/spotting, lalu menstruasi akan menjadi jarang atau berhenti sama sekali), berat badan menjadi naik, tidak bisa seketika menjadi subur, gairah seks berkurang, sakit kepala, nyeri payudara, perubahan mood dan jerawat (Wulan Sari et al., 2015).

Sebagian besar kelangsungan dari pemakaian alat kontrasepsi yang berhenti menggunakan mempunyai alasan dikarenakan ingin menambah anak, alih metode kontrasepsi yang sesuai dan adanya kendala kesehatan. Namun, satu dari beberapa yang memutuskan penggunaan alat KB dikarenakan timbulnya dampak (Purwaningrum, 2019). Beberapa penelitian membuat kesimpulan bantuan yang bermutu untuk klien adalah aspek penting dalam penerimaan penggunaan $\mathrm{KB}$ dan keberlangsungan pemakaian alat kontrasepsi. Klien akan meyalahkan ketika terdapat masalah yang timbul atau terdapat dampak yang muncul dari alat kontrasepsi yang digunakan. Hal semacam ini merupakan reaksi yang timbul sebagai dampak dari minimnya diskusi ke tenaga kesehatan dan minimnya pengetahuan tentang metode $\mathrm{KB}$ yang digunakan.

Supaya tenaga kesehatan cakap memberitahukan fakta atau KIE pada klien atau akseptor KB sehingga tenaga kesehatan harus mampu melakukan sebuah kegiatan sosialisasi tentang metode kontrasepsi dan efek samping yang mungkin terjadi sehingga dapat tersampaikan pada akseptor KB. Kegiatan tersebut dapat melihat pada pola penggunaan rasional dari alat kontrasepsi, mengena dan berdaya guna, sehingga dapat ditanggulangi tingkat kejadian drop out, keluh kesah efek samping kontrasepsi / kasus dalam kesehatan dapat diatasi (JNPKKR/POGI, BKKBN, 2014).

Dari data register yang diambil pada tahun 2020 di PBM Desa Suko Kabupaten Sidoarjo, akseptor KB suntik 3 bulan yang menghadapi efek samping sebanyak $87 \%$ dan akseptor yang tidak menghadapi efek samping KB sebanyak $13 \%$. Berdasarkan latar belakang tersebut bahwa hampir semuanya akseptor kontrasepsi suntik 3 bulan menghadapi efek samping, tujuan penelitian adalah mengkaji kejadian efek samping KB suntik 3 bulan terhadap kelangsungan penggunaan $\mathrm{KB}$ suntik 3 bulan.

\section{METODE PENELITIAN}

Desain penelitian yang digunakan yaitu korelasi menggunakan pendekatan cross sectional dengan menggunakan studi retrospektif (Notoadmodjo, 2010). Populasi penelitian yaitu semua akseptor KB suntik 3 bulan yang mengalami 
efek samping spotting di PBM Desa Suko Sidoarjo sejumlah 34 akseptor. Teknik sampling yang digunakan yaitu random sampling dan didapatkan sampel sebesar 31 akseptor KB suntik 3 bulan. Penelitian dilakukan pada bulan Oktober-Desember 2020 di 3 PBM Desa Suko Sidoarjo.

Variabel dalam penelitian ini variabel independen efek samping $\mathrm{KB}$ suntik 3 bulan (spotting) sedangkan variabel dependentnya kelangsungan penggunaan KB suntik 3 bulan. Hasil dari pencapaian data dimasukkan lembar tabulasi data dan menggunakan uji stastistik $C h i$ Kuadrat untuk menganalisa (Notoadmodjo, 2010).

\section{HASIL DAN PEMBAHASAN}

Akseptor KB suntik 3 bulan yang mempunyai efek samping spotting ditunjukkan pada tabel 1 .

Tabel 1. Jumlah akseptor KB suntik 3 bulan yang mengalami efek samping spotting pada bulan Oktober-Desember 2020

\begin{tabular}{ccc}
\hline No & Nama PBM & $\begin{array}{c}\text { Jumlah akseptor } \\
\text { yang mengalami } \\
\text { efek samping } \\
\text { spotting }\end{array}$ \\
\hline 1. & PBM Delima Husada & 12 \\
2. & PBM Delta Mutiara & 16 \\
3. & PBM Ny. S & 6 \\
\hline & Jumlah & 34 \\
\hline
\end{tabular}

Dari tabel 1 diketahui jumlah akseptor KB suntik 3 bulan yang mengalami efek samping (spotting) bulan Oktober-Desember 2020 di PBM desa Suko Kabupaten Sidoarjo sebanyak 34 akseptor. Dari sejumlah populasi tersebut didapatkan sampel 31 akseptor.

Terdapat beberapa dari data yang khusus dan juga diteliti oleh peneliti yaitu efek samping (spotting), kelangsungan penggunaan KB suntik 3 bulan dan hubungan antara efek samping $\mathrm{KB}$ suntik 3 bulan (spotting) dengan kelangsungan penggunaan KB suntik 3 bulan.

Tabel 2. Distribusi Frekuensi Jumlah Akseptor KB suntik 3 bulan yang Mengalami Efek samping

\begin{tabular}{lcc} 
Efek samping (spotting) & Jumlah & Persentase \\
\hline Kadang-kadang terjadi & 26 & $83,87 \%$ \\
Sering terjadi & 5 & $16,12 \%$ \\
\hline \multicolumn{1}{c}{ Jumlah } & 31 & $100 \%$ \\
\hline
\end{tabular}

Berdasarkan dari hasil penelitian di tabel 2 hampir seluruhnya akseptor $\mathrm{KB}$ suntik 3 bulan yang mengalami efek samping (spotting) kadangkadang terjadi sebanyak 26 akseptor KB $(83,87 \%)$.

Gangguan menstruasi sering berlangsung pada pemberian alat kontrasepsi suntikan, diantaranya yang terjadi yaitu spotting, tidak mendapatkan haid (amenore), oligomenore, polimenore, hipermenore dan hipomenore.

Hal ini sesuai dengan penelitian yang telah dilakukan Rizqi U (2014) bahwa sebagian besar dari akseptor KB suntik 3 bulan di Puskesmas pembantu Bandung Desa bandung kecamatan Diwek Kabupaten Jombang mengalami gangguan Haid berupa spotting (Rizqi U, 2014).

KB suntik 3 bulan berisi kandungan DepoProvera yaitu suatu suspensi cair yang berisi kristal mikro depo medroksi progesteron asetat (DMPA). DMPA merupakan progestin yang mekanisme kerjanya mempunyai tujuan menghambat sekresi hormon sehingga wanita yang menggunakan KB suntik 3 bulan akan tidak haid. Mekanisme kerja dari DMPA sendiri antara lain menghambat sekresi FSH dan LH serta menghambat lonjakan dari LH, implantasisel ovum tidak didukung oleh endometrium karena mengalami atrofi, lendir menjadi kental dan menjadi sulit dipenetrasi sperma serta sulit kemungkinan sperma untuk dapat bertahan hidup (Mulyani S.N dan Rinawati M, 2014). Mekanisme kerja yang terjadi tersebut dapat menyebabkan pada gangguan haid seperti spotting, tidak haid lebih dari 3 bulan, perdarahan menstruasi lebih lama atau lebih banyak dari seperti biasanya dan perdarahan terjadi diluar menstruasi (Sulistyawati, 2011), dapat pula terjadi siklus menstruasi menjadi lebih singkat dari biasanya atau kurang 21 hari dan siklus menstruasi menjadi lebih panjang atau lebih dari 35 hari.

Tabel 3. Distribusi Frekuensi Kelangsungan KB Suntik 3 bulan

\begin{tabular}{lcc}
\hline $\begin{array}{c}\text { Kelangsungan } \\
\text { Penggunaan KB suntik } \\
\text { 3 bulan }\end{array}$ & Jumlah & Persentase \\
\hline Tetap memakai KB & 23 & $74,19 \%$ \\
Drop Out & 8 & $25,81 \%$ \\
\hline \multicolumn{1}{c}{ Jumlah } & 31 & $100 \%$ \\
\hline
\end{tabular}

Berdasarkan tabel 3 menunjukkan bahwa akseptor KB suntik 3 bulan yang sebagian besar tetap memakai $\mathrm{KB}$ suntik 3 bulan $(74,19 \%)$ dan hampir setengahnya yang memutuskan untuk drop out $(25,81 \%)$. 
Tabel 4. Tabel Kontingensi Efek Samping KB Suntik 3 Bulan (Spotting) dengan Kelangsungan Penggunaan KB Suntik 3 Bulan

\begin{tabular}{|c|c|c|c|}
\hline \multirow{2}{*}{$\begin{array}{l}\text { Efek Samping } \\
\text { Spotting }\end{array}$} & \multicolumn{2}{|c|}{$\begin{array}{c}\text { Kelangsungan KB } \\
\text { Suntik } 3 \text { bulan }\end{array}$} & \multirow{2}{*}{$\underset{\mathbf{h}}{\text { Jumla }}$} \\
\hline & $\begin{array}{c}\text { Tetap } \\
\text { memakai }\end{array}$ & $\begin{array}{c}\text { Drop } \\
\text { Out }\end{array}$ & \\
\hline $\begin{array}{l}\text { Kadang-kadang } \\
\text { terjadi }\end{array}$ & 20 & 6 & 26 \\
\hline Sering terjadi & 3 & 2 & 5 \\
\hline Jumlah & 23 & 8 & 31 \\
\hline
\end{tabular}

Berdasarkan tabel 4. menunjukkan bahwa akseptor yang kadang-kadang mengalami efek samping (spotting) tetap memakai KB suntik

Tabel 5. Uji Statistic Hubungan Efek Samping KB Suntik Kombinasi (Spotting) Dengan Kelangsungan Akseptor KB Suntik Kombinasi

\begin{tabular}{lccc}
\hline & \multicolumn{2}{c}{$\begin{array}{c}\text { Kelangsungan } \\
\text { Eenggunaan KB } \\
\begin{array}{c}\text { Samping } \\
\text { (Spotting) }\end{array}\end{array}$} & \multicolumn{2}{c}{ Suntik 3 bulan } & Jumlah \\
\cline { 2 - 3 } & $\begin{array}{c}\text { Tetap } \\
\text { memakai }\end{array}$ & $\begin{array}{c}\text { Drop } \\
\text { Out }\end{array}$ & \\
\hline $\begin{array}{l}\text { Kadang- } \\
\text { kadang } \\
\text { Sering terjadi }\end{array}$ & $3,70(\mathrm{c})$ & $1,29(\mathrm{~d})$ & 5 \\
\hline \multicolumn{1}{c}{ Jumlah } & 23 & 8 & 31 \\
\hline
\end{tabular}

Berdasarkan Uji statistik Chi-Kuadrat dengan taraf signifikan 0,05 didapatkan ${ }_{2} X=2,981823$ sedangkan ${ }_{2} X$ tabel Chi-Kuadrat dan d.b=1 yaitu sebesar 3,481. Sehingga didapatkan hasil ${ }_{2} X$ hitung lebih kecil dari ${ }_{2}$ Xtabel Chi-Kuadrat (hipotesa Ho diterima). Kesimpulan dari perhitungan yaitu tidak terdapat hubungan signifikan efek samping (spotting) dengan kelangsungan penggunaan $\mathrm{KB}$ suntik 3 bulan.

Hasil penelitian ini sejalan dengan penelitian yang dilakukan oleh Sarmauli (2018) dengan kesimpulan tidak ada hubungan antara penggunaan KB suntik 3 bulan dengan gangguan haid (Sarmauli Franshisca Sihombing, 2019).

Terjadinya pemutusan pemakaian alat kontrasepsi pada akseptor KB dipengaruhi beberapa faktor, antara lain : Peran pengambil keputusan. Faktor terpenting dalam menentukan untuk tetap menggunakan atau tidak lagi menggunakan alat kontrasepsi yaitu peran pengambil keputusan atau peran suami, Jika terjadi kesalahan dalam pemanfaatan pelayanan kesehatan, perempuan sering menjadi pihak yang akan disalahkan. Hal ini terjadi disebabkan karena tingkat pendidikan, faktor kemiskinan dan motivasi ber-KB yang rendah.

Faktor yang kedua adalah pengalaman menggunakan KB, suatu faktor yang dapat menunjang pemakaian $\mathrm{KB}$ yaitu dari pengalaman menggunakan salah satu kontrasepsi. Apabila mempunyai suatu pengalaman yang tidak baik pada KB seperti terjadi efek samping yang berat. Hal ini akan menjadi argumen kuat akseptor untuk berakhir begitu pula sebaliknya sebuah pengalaman yang bagus akan menjadi pengerak akseptor untuk terus menggunakan $\mathrm{KB}$ dan akan mengulangi alat kontrasepsi yang pernah digunakan sebelumnya.

Faktor ketiga yaitu adanya putus pakai. Para akseptor KB mengungkapkan berbagai alasan untuk mereka berhenti menggunakan alat kontrasepsi setelah 5 tahun penggunaan. Alasan utama disebabkan keinginan hamil, terdapat efek samping $\mathrm{KB}$, timbulnya masalah kesehatan, kegagalan dalam berKB dan menginginkan ganti cara alat kontrasepsi yang lebih efektif.

Sedangkan faktor keempat yaitu faktor status sosial. Pendidikan yang lebih tinggi pada perempuan akan cenderung memberitahu perolehan suatu informasi serta melakukan KIE dengan lebih baik dibandingkan pendidikan rendah, semakin tinggi dari tingkatan pengetahuan orang maka semakin gampang pula memperoleh informasi dan edukasi KB terutama metode kontrasepsi.

Faktor kelima adalah usia, merupakan faktor yang dapat memberikan pengaruh seseorang untuk menjadi akseptor karena umur mempunyai kaitan dengan reproduksi seseorang dan mampu memberikan pengaruh untuk menggunakan alat kontrasepsi.

Faktor keenam ialah tempat tinggal. Pandangan terhadap pelayanan-pelayanan sosial yang diberikan akan dipengaruhi oleh tempat tinggal individu berada, tempat tinggal daerah kota mempunyai kecenderungan perbedaan pendapat dan perbuatan terhadap mutu pada pelayanan Keluarga Berencana (Mulyani S.N dan Rinawati M, 2014).

Tuntutan peningkatan mutu dari pelayanan kontrasepsi suntik dan dukungan pengayoman medis mengikuti kelangsungan akan pemakaian KB suntik, supaya kelestarian penggunaan kontrasepsi suntik selalu terjaga maka tuntutan ini harus dicukupi. Maka sebab itu, perlu meningkatkan pengetahuan dan ketrampilan tenaga kesehatan dalam memberikan pelayanan kontrasepsi terutama pada kontrasepsi suntik termasuk penyelesaian dari efek samping. Drop out dan isu berlebihan tentang program Keluarga Berencana dapat terjadi karena penanggulangan efek samping yang kurang tepat (Sulistyawati, 2011). 


\section{KESIMPULAN DAN SARAN}

Berdasarkan hasil dan pembahasan penelitian dapat disimpulan sebagai berikut: hampir seluruh akseptor KB suntik 3 bulan mendapati efek samping (spotting) dan sebagian besar memutuskan untuk tetap menggunakan KB suntik 3 bulan serta efek samping (spotting) tidak ada hubungan dengan kelangsungan penggunaan KB suntik 3 bulan.

Saran untuk penelitian selanjutnya agar melakukan penelitian dengan faktor efek samping yang lain terhadap kelangsungan penggunaan KB suntik 3 bulan sehingga angka kejadian drop out pada KB suntik 3 bulan tidak meningkat.

\section{REFERENSI}

Harini, R. (2010). Perbedaan Pengaruh Pemakaian Kontrasepsi Suntik (Cyclofem Dan Depoprogestin) Terhadap Peningkatan Tekanan Darah Pada Wanita Usia Subur Di Wilayah Kerja Puskesmas Pakisaji Malang. Jurnal Keperawatan.

JNPKKR/POGI, BKKBN, D. J. (2014). Buku Panduan Praktis Pelayanan Kontrasepsi. Yayasan Bina Pustaka Sarwono.

Kolifah, Nugroho, B., \& Hidayah, M. (2013). FaktorFaktor Yang Mempengaruhi Tingginya Cakupan Akseptor $\mathrm{Kb}$ Memilih Metode $\mathrm{Kb}$ Suntik 3 Bulan Di Desa Cupak Kecamatan Ngusikan Kabupaten Jombang. Jurnal Metabolisme.https://doi.org/10.16192/j.cnki.10 03-2053.2018.02.014

Mulyani S.N dan Rinawati M. (2014). Keluarga Berencana dan Alat Kontrasepsi. Nuha Medika.
Notoadmodjo. (2010). Metode Penelitian Kesehatan. Gramedia Pustaka Utama.

Prasetyo, T. (2013). Analisis Faktor Yang Mempengaruhi Pus Mengikuti Keluarga Berencana (KB) Di Wilayah Kerja Puskesmas Sambirejo Kabupaten Sragen. Naskah Publikasi.

Purwaningrum, Y. (2019). Efek Samping KB IUD (Nyeri Perut) Dengan Kelangsungan Penggunaan KB IUD. Jurnal Kesehatan, 5(1). https://doi.org/10.25047/j-kes.v5i1.50

Rizqi U. (2014). Gangguan Haid Pada Akseptor Kb Suntik 3 Bulan Di Pustu Bandung, Desa Bandung, Kecamatan Diwek, Kabupaten Jombang.

Sarmauli Franshisca Sihombing. (2019). Hubungan Pemakaian Kb Suntik 3 Bulan Dengan Gangguan Haid Di Puskesmas Baloi Permai Kota Batam. Jurnal Keperawatan, 9(1).

Septianingrum, Y., Wardani, E. M., \& Kartini, Y. (2018). Faktor-Faktor Yang Mempengaruhi Tingginya Akseptor Kb Suntik 3 Bulan. Jurnal Ners Dan Kebidanan (Journal Of Ners And Midwifery). https://Doi.Org/10.26699/Jnk.V5i1.Art.P01 5-019

Sulistyawati, A. (2011). Pelayanan Keluarga Berencana. Salemba Medika.

Wulan Sari, S., Suherni, \& Purnamaningrum, Y. E. (2015). Gambaran Efek Samping ontrasepsi Suntik Pada Akseptor Kb Suntik. Kesehatan Ibu Dan Anak. 